\title{
Konseling Islami sebagai Intervensi bagi Remaja Berisiko di Madrasah
}

\author{
Muhamad Rozikan \\ IAIN Salatiga, Jawa Tengah, Indonesia \\ rozikanmuhamad@gmail.com
}

\begin{abstract}
Abstrak
Era modern memberi dampak yang signifikan terhadap Perkembangan remaja yang sangat kompleks. Usia remaja rentan terhadap perilaku-perilaku yang membahayakan dan penuh risiko, rasa ingin tahu remaja yang besar, keinginan untuk mencoba atau mempraktikkan, unjuk kekuatan atau gagah-gagahan dan rasa ingin diakui dalam lingkungannya. Perilaku-perilaku berbahaya dan beresiko pada remaja perlu menjadi perhatian bagi konselor madrasah. Konseling Islami di madrasah merupakan suatu layanan konseling yang berbasis ajaran-ajaran Islami dengan melandaskan kepada al-Qur'an, Hadits, ijma' dan qiyas. Konseling Islami merupakan bentuk-bentuk layanan yang menggunakan design sesuai kaidah dan ajaran agama Islam. Pemecahan masalah atau problem solving dalam Konseling Islami ini tidak terlepas dari petunjuk dalam ayat-ayat suci al-Quran dan hadist Rasulullah saw. Konseling Islami sangat membantu dalam peranannya sebagai posisi sentral dalam usaha memperkuat pencegahan, pengarahan, pembinaan, bahkan sampai tataran pengentasan terhadap remaja di madrasah dari perilaku berisiko.
\end{abstract}

Kata Kunci: Konseling Islami, Remaja Berisiko, Madrasah.

\begin{abstract}
The modern era has a significant impact on the development of adolescents who are very complex. Teenagers are prone to dangerous and risky behaviors, great adolescent curiosity, the desire to try or practice, show strength or stoutness and a sense of wanting to be recognized in their environment. Dangerous and risky behaviors in adolescents need to be a concern for madrasa counselors. Islamic counseling in
\end{abstract}




\section{Konseling Islami sebagai Intervensi bagi Remaja Berisiko di Madrasah}

madrasah is a counselling service based on Islamic teachings with the underpinning to the Qur'an, Hadith, ijma' and qiyas. Islamic counseling is a service form that uses design according to the rules and teachings of the Islamic religion. Problem solving or problem solving in Islamic Counseling is inseparable from the instructions in the holy verses of the Koran and the hadith of the Prophet. Islamic counseling is very helpful in its role as a central position in an effort to strengthen prevention, direction, guidance, even to the level of alleviation of adolescents in madrasa from risky behavior. Keywords: Islamic Counseling, Youth At Risk, The Madrasa.

\section{A. Pendahuluan}

Masalah kenakalan remaja dewasa ini semakin dirasakan meresahkan masyarakat, baik di negara-negara maju maupun negara-negara yang sedang berkembang. Dalam kaitan ini, masyarakat Indonesia telah mulai pula merasakan keresahan tersebut, terutama mereka yang berdomisili di kota-kota besar. Akhir-akhir ini masalah tersebut cenderung menjadi masalah nasional yang dirasa semakin sulit untuk dihindari, ditanggulangi, dan diperbaiki kembali.

Keberadaan kenakalan anak remaja di Indonesia saat ini merambah segi-segi kriminal yang secara yuridis formal menyalahi ketentuan. Kondisi ini jauh lebih rumit daripada sekedar kondisi destruktif dalam perspektif norma-norma sosial dan susila. Diselasela kondisi destruktif yang serba rumit itu, para ilmuwan, rohaniawan, pemuka masyarakat dan pemerintah telah berusaha secara, maksimal untuk melakukan langkah - langkah nyata guna mencegah dan menanggulangi kenakalan remaja. Termasuk juga usaha memperbaiki kembali serta meresosialisasi anak - anak yang terlibat dalam kenakalan remaja. Walaupun usaha tersebut telah dilakukan secara intensif oleh pemerintah bersama masyarakat, namun tingkat keberhasilannya masih tahap analisis (Sudarsono, 1995:5).

Perilaku-perilaku berbahaya dan penuh resiko pada diri remaja terutama pada siswa di madrasah antara lain, berpacaran, melakukan hubungan sex di luar nikah, merokok bahkan mendekati penyalahgunaan obat-obat terlarang, narkoba, begadang sampai 
larut malam tanpa ada manfaat, kebut-kebutan sepeda motor atau mobil secara liar, berkelahi sampai tawuran, melihat film-film porno, meminum minuman keras, kriminalitas dan lain-lain.

Perilaku-perilaku atau sikap remaja seperti di atas akan menjadi perilaku-perilaku yang sangat berbahaya dan penuh risiko bila remaja-remaja tersebut tidak mendapatkan pengawasan, pendampingan, nasehat dan contoh yang baik dari lingkungannya, orang tua, budaya dan pola asuh keluarga, guru dan konselor sekolah dan sebagainya. Sikap perhatian dan kepedulian dari semua pihak akan menghasilkan remaja sebagai generasi muda menjadi berkualitas dan bermartabat.

Perilaku berisiko merujuk pada semua perilaku yang dapat membahayakan aspek psikososial dari perkembangan remaja. Setiap perilaku berisiko tersebut saling mempengaruhi atau tidak terpisah satu dengan yang lainnya. Dalam upaya pembentukan identitas (identity versus identity confusion) remaja yang memiliki identitas diri positif disebut sebagai remaja yang mampu melakukan penyesuaian dengan perubahan-perubahan dalam diri maupun dari luar, misalnya perubahan biologis, pola berpikir, status dan peran sosial.

Perubahan - perubahan dalam perkembangan remaja akan mendorong hadirnya peran-peran baru dan status kedewasaan bagi remaja. Peran-peran tersebut harus didapatkan dengan cara yang baik, yang akhirnya bertujuan untuk mendapatkan identitas positif. Apabila suatu identitas dipaksakan pada remaja, dan remaja tidak mampu mencapainya maka kebingungan identitas akan terjadi. Kondisi demikian yang seringkali menjadi peristiwa pencetus bagi remaja untuk melakukan perilaku berisiko.

Penyebab secara internal adalah karena memang masa remaja sebagai bagian dari tahap perkembangan manusia tersebut berada pada masa transisi dari masa anak-anak menuju ke masa dewasa, masa pencarian jati diri dan identitas, masa terombangambingnya sikap mental, masa pencarian bentuk dan karakter dan sebagainya.

Penyebab secara eksternalnya adalah pola asuh keluarga yang tidak tepat, produk dari broken home, penanaman nilai-nilai budaya dan keimanan kepada Allah swt, penyalahgunaan teknologi 
informasi yang keliru, lingkungan pergaulan yang tidak sehat dan lain-lain.

\section{B. Pembahasan}

\section{Konseling Islami}

Konseling Islami di madrasah merupakan proses konseling yang juga berorientasi kepada tujuan pendidikan Islam, dan bertujuan membangun kehidupan sakinah, kehidupan tidak hanya sekedar mencapai kemakmuran, tetapi juga ketentraman hidup spiritual. bimbingan kehidupan yang pada intinya tertuju kepada realisasi do'a rabbana atina fiddunya hasanah wa fil akhirati hasanah wa qina adza banner, berisikan jalan kearah penyadaran kerpibadian manusia sebagai makhluk Allah, dengan menumbuhkan rasa tentram dalam hidup karena selalu merasa dekat dengan Allah dan dalam lindunganNya.

Hal ini jelas bahwa konseling Islami juga merupakan proses konseling yang berorientasi pada ketentraman hidup manusia dunia akhirat. Pencapaian rasa tenteram (sakinah) itu adalah melalui upaya pendekatan diri kepada Allah serta melalui upaya untuk memperoleh perlindunganNya. Terapi sakinah itu akan menghantarkan individu untuk berupaya sendiri dan mampu menyelesaikan masalah kehidupannya. Dengan demikian, secara tegas dikatakan bahwa konseling Islami mengandung dimensi spiritual dan dimensi material. Dimensi spiritual adalah membimbing manusia pada kehidupan rohaniah untuk menjadi beriman dan bertakwa kepada Allah. Sedangkan dimensi material membantu manusia untuk dapat memecahkan masalah kehidupan agar dapat mencapai kemajuan. Prinsip- prinsip inilah yang dengan tegas membedakan konsep konseling Islami dengan konsep konseling hasil dari pengetahuan dan empirik barat.

\section{Visi, Misi dan Tujuan BK Islami di Madrasah}

Visi konseling Islami di madrasah adalah menjadikan konseling Islami sebagai salah satu kerangka berpikir dan kerangka bertindak bagi manusia (klien) yang mampu memelihara dan meningkatkan komitmen beragama berdasarkan nilai-nilai Islam 
menuju kebahagiaan dunia dan akhirat yang dapat memberi kontribusi positif bagi lingkungannya serta memperoleh ridha Allah swt.

Berdasarkan visi tersebut di atas, maka misi konseling Islami di madrasah adalah sebagai berikut: a) Membantu insan akademis (klien) untuk mampu memelihara dan meningkatkan keimanan kepada Allah swt, sesuai syariat Islam, b) Membantu insan akademis (klien) untuk mampu memelihara dan meningkatkan keislaman sesuai syariat Islam, c) Membantu insan akademis (klien) untuk mampu memelihara dan meningkatkan keihsanan sesuai syariat Islam.

Tujuan utama konseling Islami di madrasah adalah menumbuhkan sikap konsisten akan ajaran Islam (memiliki komitmen terhadap Islam). Selain itu, konseling Islami pun bertujuan agar manusia memiliki kesadaran akan eksistensi dirinya, konsisten dalam menjalankan agama Allah disertai dengan kesehatan mental yang sejalan dengan nilai-nilai hukum syar'i (Az-Zahrani, 2005:34).

Lebih lanjut Az-Zahrani mengemukakan bahwa konseling Islami di madrasah memiliki tujuan khusus, diantaranya adalah: a) Membina keimanan yang kokoh dalam jiwa hingga mampu menjadikan jiwa individu diliputi dengan rasa aman, tenang, ridha dengan segala yang ditakdirkan Allah dan juga sehat secara mental, b) Memberikan suri teladan yang baik yang didasari kaidah-kaidah dasar yang telah ditetapkan Allah swt, c) Menghormati kemuliaan manusia yang berlandaskan atas akhlak yang mulia, diantaranya seperti menolong, toleransi dan juga rasa optimis, d) Memberikan proses konseling tidak dengan sesuatu yang diharamkan, seperti paranormal ataupun sihir dalam mengatasi berbagai permasalahan yang ada ataupun memenuhi berbagai kebutuhan hidup.

Adapun tujuan penerapan konseling Islami di madrasah dalam jangka pendek adalah sebagai berikut: a) Agar klien/siswa mampu mengikuti petunjuk yang diberikan Allah swt dengan mengikuti petunjuk Allah itu klien tidak akan tersesat, selamat, terhindar dari hal-hal yang membahayakan dirinya dan lingkungan sekitarnya dan yang lebih penting lagi adalah agar klien bisa hidup bahagia dan sejahtera dalam naungan Allah swt, b) Agar klien/siswa tidak mengikuti hawa nafsu dan segera kembali ke jalan Allah. Dengan 


\section{Konseling Islami sebagai Intervensi bagi Remaja Berisiko di Madrasah}

terlepasnya klien dari pengaruh setan dan tidak mengikuti hawa nafsu, maka jiwa klien akan menjadi bersih dan dengan jiwa yang bersih itu memungkinkan klien akan lebih mudah menerima nasihat yang benar, c) Agar klien/siswa dapat memahami dan menerima cobaan atau ujian yang sedang diberikan Allah swt sabar an tawakkal. Dengan kemampuan memahami dan menerima cobaan Allah dengan sabar dan tawakkal diharapkan klien bisa memiliki kesiapan diri untuk menerima dan menyelesaikan masalah-masalah yang dihadapinya sesuai tuntunan Allah. Dengan kesabaran itu diharapkan klien tidak mudah terombang-ambing dalam menyelesaikan masalah yang dihadapi dan terhindar dari cara-cara penyelesaian masalah yang tidak diridlai Allah. Dan dengan sikap tawakkal yang diharapkan klien akan tenang dalam menunggu hasil usahanya. Dengan pemahaman yang benar terhadap masalah yang dihadapi diharapkan klien akan terbuka kesadarannya bahwa dibalik ujian berupa maslah itu mungkin ada sesuatu yang perlu diluruskan dari jalan yang salah yang ditempuh selam ini, dan juga kesadaran bahwa dibalik ujian itu ada "hikmah" yang belum diketahui, dan atau Tuhan hendak meningkatkan kualitas keimanannya dengan memberi ujian atau cobaan, d) Agar klien/siswa menggunakan akal pikiran, perasaan dan tuntunan agama sebagai pengendali nafsu dan sekaligus pedoman dalam mengembangkan dan memfungsikan potensi yang dianugrahkan Allah kepadanya, e) Agar klien/siswa memiliki kepribadian yang kokoh dan tidak mudah diombangambingkan oleh fatwa dan atau pendapat yang menyesatkan. Untuk itu klien perlu memiliki filter berupa ajaran yang benar.

Adapun tujuan penerapan konseling Islami di madrasah dalam jangka panjang adalah agar klien selalu memiliki komitmen terhadap ajaran agamanya yang termanifestasikan dalam kehidupan seharihari dan mendapat kebahagiaan yang sejati di dunia dan akhirat.

Selain tujuan di atas, tujuan instrumental perlakuan dalam konseling Islami adalah agar manusia (klien) memiliki kesadaran akan eksistensi dirinya, konsistensi daam menjalankan agama Allah disertai dengan kesehatan mental dengan selalu mengharap ridha Allah swt. Tingkat komitmen beragama yang tinggi mendorong terhindarnya klien dari gangguan stress yang disebabkan oleh ketidakmampuan mengatasi masalahnya. Dimensi komitmen 
beragama meliputi keimanan yang tinggi, keislaman yang tinggi, dan keihsanan yang tinggi.

\section{Perilaku Remaja Berisiko di Madrasah}

Perubahan dari seorang anak menjadi remaja dan setelah itu menjadi dewasa melibatkan jauh lebih banyak dari pada sebuah progesi perubahan linier. Ia bersifat multidimensional, melibatkan transformasi gradual atau metamorphosis pribadi sebagai seorang anak menjadi orang baru sebagai orang dewasa. Selama proses ini, berbagai perubahan psikologis, fisiologis, biologis dan sosial harus dihadapi.

Setiap hari, lazim untuk membaca tentang berbagai tuntutan dan stress yang semakin banyak dihadapi oleh remaja/siswa di madrasah. Sebagai contoh menemukan pekerjaan di dalam kondisi yang kompetitif, mengembangkan hubungan dengan orang lain, tuntutan untuk self-organization, dan adaptasi dengan teknologi semuanya memberikan tantangan dan mereka kemungkinan besar akan dialami sebagai sesuatu yang stressful. Di samping itu, banyak remaja/siswa mengalami kecemasan dan stress yang berkaitan dengan keselamatan dana keemanan pribadi di zaman peristiwa nasional dan internasional yang sering kali mengkhawatirkan dan mengganggu. Akan tetapi, penting bagi kita untuk mengakui bahwa ada perbedaan individual, sebagai remaja mengatasi tantangan ini dengan lebih mudah dibanding yang lain. Mereka yang tidak mampu bernegoisasi dengan tantangan yang mereka hadapi dengan sukses akan mengalami kegagalan, yang mungkin mengakibatkan kerugian emosional dan psikologis.

Akibat banyaknya tantangan sulit yang dihadapi remaja, sering kali untuk pertama kalinya dalam hidup mereka, semua remaja seharusnya dianggap sebagai individu-individu berisiko tinggi. Penting untuk diingat bahwa ada banyak remaja yang memiliki kebutuhan tertentu atau menghadapi isu tertentu yang membuat hidup mereka sangat sulit ditangani. Jelas, tantangan yang tetap ada terlepas dari usaha seorang remaja untuk mengatasinya akan berkemungkinan untuk membahayakan kesejahteraan jangka panjang mereka kecuali jika diberikan bantuan-bantuan spesifik dan informed (Kathryn Geldad : 2012: 8). 
Beberapa perilaku dinyatakan berisiko, dalam arti apabila perilaku tersebut dilakukan akan berpeluang untuk menimbulkan kerugian bagi pelakunya. Peluang tidak berarti bahwa pasti terjadi. Sekarang maupun di masa yang akan datang. Terhadap diri sendiri maupun terhadap orang lain. Kerugian dapat berupa kerugian material, fisik, harga diri, rasa malu, kehilangan kesempatan, kehilangan masa depan, dan seterusnya.

Masa remaja adalah media tahapan perkembangan yang sangat rentan dan berpotensi melakukan perilaku-perilaku berisiko. Wawasan yang masih terbatas, rasa ingin tahu dan penasaran yang besar, ingin coba-coba, minimnya pengawasan dan pendampingan dari guru dan orang tua atau keluarga, gaya hidup dan budaya, pergaulan yang bebas, pendidikan iman dan agama yang kurang, semuanya berpotensi terjadinya perilaku beresiko. Contoh perilaku beresiko pada remaja adalah: berpacaran yang bisa menimbulkan bahaya sex bebas, mulai dari berpegangan tangan sampai dengan hubungan sex diluar nikah, berganti ganti pasangan, merokok dan penyalahgunaan obat-obat terlarang dan narkoba, hubungan cinta sesama jenis, kebiasaan sex menyimpang seperti onani dan masturbasi, begadang dan minum minuman keras, melihat video porno, bulying dan lain sebagainya.

\section{Aspek-Aspek Positif Risiko di Madrasah}

Semua remaja rentan terhadap resiko dan perilaku mengambil risiko, karena ini adalah salah satu bagian tak terhindarkan dari tahap perkembangan mereka. Alih-alih membahas ide bahwa "risk taking" (perilaku pengambil resiko adalah respon tanpa pandang bulu terhadap kesulitan yang sebelumnya tak teratasi atau perebutan kekuasaan dengan orang tua dan /atau masyarakat, mungkin akan membantu untuk mendifinisikan kembali tantangan ini sebagai sesuatu yang berkontribusi pada proses pertumbuhan yang secara potensial positif, di mana tantangan dan risiko adalah alat primer yang digunakan remaja untuk menentukan siapa dirinya dan menentukan akan menjadi siapakah dirinya kelak. Memahami cara remaja memaknai hidup mereka melalui pengalaman pribadinya sendiri adalah penting ketika melibatkan mereka secara kolaboratif di dalam intervensi untuk solusi. Mengakui bagaimana pengalaman itu dipengaruhi oleh keluarga, masyarakat yang lebu luas, budaya, 
lingkungan, faktor-faktor sosial-ekonomi dan politik, dan yang terpenting isu-isu perkembangan sentral bagi proses kolaboratif memlih intrevensi yang cocok untuk masing-masing remaja.

\section{Intervensi Konseling Islam Bagi Remaja Berisiko di Madrasah}

Pelaksanaan konseling Islami di madrasah, konselor madrasah ketika membantu klien/konseli itu harus berdasarkan beberapa prinsip atau asas, diantaranya adalah :

1. Asas kebahagiaan dunia dan akhirat. Konseling Islami membantu orang dengan tujuan agar orang yang dibantu (klien) mencapai kebahagiaan hidup di dunia dan akhirat yang senantiasa didambakan oleh setiap muslim, seperti dalam QS Albaqarah/2:201, QS Ar-Ra'd/13:26, 28 dan 29, QS Qashas/28:77. Pentingnya keseimbangan, keselarasan dan keserasian antara kehidupan dunia dan akhirat dinyatakan juga oleh sabda Rasulullah saw : "Bekerjalah untuk kepentingan duniamu seolaholah kamu akan hidup abadi, dan bekerjalah untuk kepentingan akhiratmu seolah-olah kamu akan mati esok hari" (HR Ibnu Asakir).

2. Asas Fitrah. Konseling Islami merupakan bantuan kepada klien untuk mengenal, memahami, dan menghayati fitrahnya, sehingga segala tingkah laku dan gerakannya sejalan dengan fitrahnya tersebut. Sehubungan dengan fitrah ini Rasulullah saw bersabda: "Setiap manusia dilahirkan ibunya dalam keadaan fitrah. Maka kemudian ayah ibunyalah yang menjadikannya yahudi, nasrani, atau majusi. Dan jika ayah ibunya seorang muslim, maka jadilah (anak) seorang muslim". (HR Muslim), dan dalam QS Ar-Rum :30. Bimbingan dan Konseling membantu klien mengembangkan bakat, kemampuan atau potensi klien seoptimal mungkin, karena fitrah kerap kali juga diartikan sebagai bakat, kemampuan atau potensi seseorang.

3. Asas lillahi ta'ala. Konseling Islami diselenggarakan semata-mata karena Allah, seperti firman Allah dalam QS Al-An'am/6:162, QS Adz-Dzariyat/51:56, QS Al-Bayyinah/98:5.

4. Asas bimbingan seumur hidup. Dalam kehidupan mungkin saja manusia akan menjumpai berbagai kesulitan dan kesusahan. 
Oleh karena itulah bimbingan dan konseling Islami diperlukan selama hayat masih dalam kandungan.

5. Asas kestuan jasmani dan rohani. Konseling Islami membantu individu untuk hidup dalam keseimbangan jasmaniah dan rohaniah, Allah mencontohkan dengan kasus seperti dalam QS Albaqarah/2:187.

6. Asas keseimbangan rohaniah. Rohani manusia memiliki unsur kemampuan piker, merasakan kehendak juga akal, sebagaimana firman Allah swt dalam QS Al-A'raf/7:179, bahwa manusia itu mempunyai hati, tetapi tidak dipergunakan untuk memahami (ayat-ayat Allah) dan mereka mempunyai mata, tetapi tidak dipergunakan untuk melihat (tanda-tanda kekuasaan Allah), dan mereka mempunyai telinga tetapi tidak dipergunakan untuk mendengar (ayat-ayat Allah).

7. Asas kemaujudan (eksistensi) individu. Konseling Islami hak, mempunyai perbedaan individu dari yang lainnya, dan mempunyai kemerdekaan pribadi sebagai konsekuensi dari haknya dan kemampuan fundamental potensial rohaniahnya, sebagaimana firman Allah dalam QS Al-Qamar/54:49, bahwa Allah menciptakan segala sesuatu menurut ukuran.

8. Asas sosialitas manusia. Manusia merupakan makhluk sosial, seperti friman Allah dalam QS An-Nisa/4:1, bahwa Allah memerintahkan manusia untuk bertakwa kepada Allah dengan mempergunakan nama-Nya kamu saling meminta satu sama lain dan memelihara hubungan silaturrahim (Nurihsan , 2006: 31).

Sedangkan menurut Anwar Sutoyo (2013: 116) prinsipprinsip yang harus dikembangkan dalam Konseling Islami mencakup fitrah yang meliputi (a) Fitrah Iman yang di dalamnya mengandung esensi : mengakui keesaan Allah dan tunduk kepadaNya. Fungsinya adalah memberi bentuk dan arah bagi fitrah. (b) Fitrah Jasmani, yang di dalamnya merupakan wadah fitrah rohani yang mencakup sistem jasmani tubuh, alat-alat indra, alat kelamin. (c) Fitrah Nafs/Jiwa sebagai paduan integral antara fitrah jasmani (biologis) dengan fitrah rohani (psikologis) dan ia memiliki 3 komponen pokok yaitu : kalbu, akal dan nafsu yang saling berinteraksi dan terwujud dalam suatu bentuk. (d) Fitrah Rohani sebagai esensi pribadi manusia, memiliki daya mengembangkan proses biologis, berada di alam materi dan 
imateri, lebih abadi daripada fitrah jasmani, suci dan memperjuangkan dimensi-dimensi spiritual dan mampu bereksistensi dan dapat menjadi tingkah laku aktual bila telah menyatu dengan fitrah jasmani.

\section{Teknik Konseling Islami}

Teknik dimaksudkan sebagai alat dan merupakan suatu alternatif yang dipakai untuk mendukung metode konseling Islami. Pendayagunaanya secara tegas akan mengacu pada petunjuk yang tertera dalam al-Qur'an dan hadis nabi, antara lain:

1. Surat an-Nahl (16) ayat 125: yang artinya "Serulah (manusia) kepada jalan Tuhanmu dengan hikmah dan pelajaran yang baik dan bantahlah mereka dengan cara lebih baik." (al-Nahl (16):125).

2. Surat Ali Imran (3) ayat 159: yang artinya "Maka disebabkan rahmat dari Allah-lah kamu berlaku lemah terhadap mereka. Sekiranya kamu bersikap keras lagi berhati kasar, tentulah mereka menjauhkan diri dari sekelilingmu. Karena itu maafkanlah mereka, mohonkanlah ampun bagi mereka, dan bermusyawarahkanlah dengan mereka dalam urusan itu. Kemudian apabila kamu telah membulatkan tekad, maka bertawakkallah kepada Allah. Sesungguhnya Allah menyukai orang-orang yang bertawakkal kepadaNya." (Ali Imran (3) : 159).

3. Hadis yang menjelaskan petunjuk nabi kepada Abu Musa alAsy'ari dan Muaz bin Jabal ketika hendak menunaikan misi khusu ke Yaman: hadis tersebut yang artinya "Permudahlah dan jangan mempersukar dan gembirakanlah 9besarkan jiwa) mereka dan jangan melakukan tindakan yang menyebabkan mereka lari darimu.

Makna yang terkandung oleh dua ayat al-Qur'an dan hadis tersebut di atas mengisyaratkan bahwa betapa sebenarnya hati nurani manusia akan mudah tersentuh dengan perlakuan dan sikap yang lemah lembut. Siapapun manusianya pasti memiliki kelembutan hati (meskipun kadarnya sedikit/lemah), dan kelembutan hati itu akan lebih terjamin merespon dengan baik jika bertemu dengan sesuatu yang lemah lembut pula. Manusia akan lebih mudah 


\section{Konseling Islami sebagai Intervensi bagi Remaja Berisiko di Madrasah}

menerima/tunduk kepada kebenaran yang disampaikan jika penyampaian itu dengan cara lemah lembut, hingga menyentuh sisi terdalam dari hati nuraninya. Hal ini seyogyanya harus disikapi konselor madrasah ketika melakukan konseling terhadap kien/konselinya. Pada saat itu konselor madrasah sedang berhadapan dengan manusia yang mengalami ketidakharmonisan, ketidakseimbangan hati/mental/jiwa, ia tidak akan mudah menerima sesuatu (arahan, petunjuk, saran, tuntutan) meskipun terjamin kebenarannya. Pada saat ini pula ia mengharapkan sesuatu (arahan, petunjuk, saran, tuntutan) yang disampaikan dengan cara lemah lebut, tidak memaksa, sehingga hati nuraninya dapat tersentuh dan rasionya membenarkan. Ia ingin dipandang bukan sebagai pesakitan yang akan dihakimi, tetapi sebagai subyek yang hendak dikembangkan.

Selanjutnya, merumuskan teknik konseling Islami harus bertitik tolak dari prinsip pemupukan penjiwaan agama pada diri klien/konseli dalam upaya menyelesaikan masalah kehidupanya. Dengan penjiwaan agama dimaksud klien/konseli diarahkan untuk menemukan sumber pola hidup agamis dalam pribadinya, sehingga ia benar-benar menyadari dan menyakini bahwa tidak ada permasalahan yang tidak dapat diselesaikan, asal saja ia bersedia kembali kepada petunjuk agama. Penjiwaan agama diintensifkan sampai pada pengalaman ajarannya. Dalam hal ini, teknik konseling Islami akan bersifat persuasive dan stimulatif terhadap munculnya kesadaran pribadi klien/konseli untuk mengamalkan ajaran agamanya. Oleh Karena itu, teknik konseling Islami dapat dirumuskan dengan: spiritualism method. Teknik ini dirumuskan atas dasar nilai yang dimaknai bersumber dari asas ketauhidan. Beberapa teknik dikelompokkan dalam spiritual method, yakni:

\section{1) Latihan spiritual}

Dalam hal ini, klien/konseli diarahkan untuk mencari ketenangan hati, dengan mendekatkan diri kepada Allah sebagai sumber kekuatan hati, sumber kekuatan dan penyelesaian masalah, sumber penyembuhan penyakit mental.

Pada awalnya, konselor menyadarkan klien/konseli agar dapat menerima masalah yang dihadapinya dengan perasaan lapang dada, bukan dengan perasaan benci dan putus asa. Masalah tersebut 
adalah menguji dan mempertaruhkan keteguhan imannya, buka sebagai wujud kebencian Allah kepadanya. Kebenaran makna alQur'an surah al-Baqarah (2) ayat 155 dan surat at-Tagabun (64) ayat 15 harus benar-benar ditanamkan ke dalam hatinya, sehingga ia benar-benar dapat memahami keberadaan dan kondisi dirinya, buka saja dihadapan masalahnya, tetapi juga di hadapan Allah. Dengan demikian, diharapkan ia akan mendekati Allah, bukan menjahuiNya.

Selanjutnya, konselor madrasah menegakkan prinsip tauhid dengan meyakinkan masalah, tempat ia berpasrah, tempat ia memohon pertolongan untuk menyelesaikan masalah. dengan sifat maha kuasa Allah, bagiNya permasalahan itu bukanlah hal yang berat untuk diselasaikan. Yang ingin dibuktikan bagaimana keimanan dan keikhlasan klien/konseli untuk menyerahkan masalahnya sepenuhnya kepada kearifan Allah. Untuk itu, kebenaran makna alQur'an surat al-Baqarah (2) ayat 112, 156, 255, dan 284, surat Ali Imran (3) ayat 159-160, surat at-Thalaq (65) ayat 3-4, harus ditegakkan dalam keyakinannya, sehingga ia dapat melakukan upaya melakukan upaya penyelesaian masalah dengan tenang.

Setelah klien/konseli dapat merasakan hal-hal positif dari apa yang dilakukannya, maka konselor mendorongnya agar ia terus melatih diri secara berkesinambungan, sehingga mengingat Allah (zikir) itu dapat dilakukannya di setiap saat, tempat, situasi dan kondisi, serta dapat menjadi bagian tak terpisahkan dari dirinya dalam menjalani tugas kehidupannya sehari-hari di tengah-tengah keaktifan dan kreatifitasnya. Dengan aktifitas zikir tersebut klien/konseli diharapkan dapat mengikis/menghilangkan sifat-sifat: riya', sombong, angkuh, hasad, dan dengki (iri hati), rakus/tamak, kikir, dusta, was-was, egois, emosional, bicara berlebihan, cinta dunia/harta/pangkat/pengaruh yang berlebihan, zalim, ingkar janji, kufur nikmat, dan lain-lain. Selanjutnya, menumbuhkembangkan sifat-sifat: rendah hati, ramah, lapang dada, pemurah, jujur, ikhlas, teguh pendirian/hati, rela, sabar, cinta kesederhanaan, welas asih, amanah, syukur nikmat, dan lain-lain. Pada gilirannya kelak ia dapat memiliki hati sehat/bersih (qolbun salim) dan jiwa tenteram (nafs mutmainnah) serta dapat merasakan hidup tenang (sakinah) dalam suasana kebahagiaan hidup dunia dan akhirat. Dengan demikian, 
tertanam pula dalam keyakinannya akan kebenaran makna al-Qur'an yang terkandung dalam surat al-Fajr (89) ayat 27-30.

\section{2) Menjalin kasih sayang}

Penjabaran teknik ini dapat ditarik dari nilai-nilai yang dimaknai pada asas kerahasiaan, pendekatan kemandirian dan pendekatan sukarela. Keberhasilan konseling Islami juga akan ditentukan oleh terciptanya hubungan baik antara konselor dan klien/konseli. Hubungan dimaksud adalah hubungan yang didasarkan atas kasih sayang (ukhuwah Islamiyah). Karena tanpanya kepercayaan klien/konseli tidak akan tumbuh, sehingga dialog tidak akan berjalan lancer, atau mungkin tidak akan terjadi, dan selanjutnya pemberdayaan tidak akan dapat dilakukan. Sedangkan proses penyembuhan penyakit mental bersangkutan. Oleh karena itu, keinginan klien/konseli untuk mendapatkan perlindungan sejak menentukan pilihan untuk berkonsultasi dengan konselor akan tumbuh dengan baik jika ia merasa bahwa layanan dilakukan konselor itu bersikap melindungi diri pribadinya. Kepercayaan klien/konseli akan berkurang, bahkan akan hilang sama sekali jika ia sudah merasa bahwa konselor bukanlah orang yang tepat sebagai pelindung dirinya dan sebagai pengganti jalan keluar bagi problemnya.

Oleh karena itu, rasa kasih sayang dan sikap lemah lembut pada klien/konseli kan sangat bermanfaat bagi keberhasilan konseling Islami. Mahmud Hasan menegaskan bahwa konselor harus memiliki sifat-sifat penting, yaitu: ikhlas, adil, sehat, jasmani dan rohani, penuh pengertian dan kasih sayang, memiliki kestabilan emosi dan lain-lain. Sedangkan Tohari Musnamar mengemukakan, bahwa pelaksanaan layanan bimbingan Islami hendaklah didasarkan atas rasa kasih sayang, karena di antara tanda-tanda kemanusiaan yang sempurna bahwa manusia itu sanggup mengasihi dan mencintai orang lain. Dalam hal pengobatan ini, al-Ghazali menyatakan bahwa hal itu harus dilakukan dengan lemah lembut dan penuh kasih sayang. Allah sebagai konselor yang maha agung memeliki sifat maha pengasih, maha penyanyang terhadap hambaNya. Oleh karena itu, konselor seyogyannya menjadikan jalinan kasih sayang sebagai teknik dalam layanan konseling Islami yang diselenggarakan. 
Perlakuan lemah lembut dan dilandasi oleh rasa kasih sayang dalam segenap hubungan dan aktivitas sesama manusia, secara jelas dapat ditemukan keterangannya pada ayat-ayat al-Qur'an dan hadis nabi, diantarannya adalah surat Maryam (19) ayat 96 dan surat Thoha (20) ayat 44, serta hadis riwayat Bukhori dan Muslim yang menjelaskan bahwa: orang yang benar-benar beriman adalah orang yang mencintai saudaranya, dan siapa tidak menyayangi orang lain, ia juga tidak akan mendapatkan kasih sayang dari siapa pun.

Dengan demikian, jelas bahwa prinsip kasih sayang merupakan rujukan penting dalam upaya mengayomi kehidupan psikis atau hati manusia . dalam hal ini, konselor dituntut untuk memiliki sifat tersebut, agar klien/konseli senantiasa dapat merasakan perlindungan dan kasih sayang yang diberikan, sehingga problem kehidupannya dapat diatasi atau minimal tidak lagi dirasakannya sebagai problem berat/berarti.

\section{3) Cerminan al-Qudwah al-Hasanah}

Penjabaran teknik ini dapat pula ditarik dari nilai yang dimaknai pada pendekatan kemandirian. Proses konseling Islami yang berlangsung secara face to face menempatkan konselor pada posisi sentral di hadapan klien/konseli. Perhatian klien/konseli terhadap konselor tidak hanya sebatas pada petunjuk-petunjuk yang diberikannya selama konsultasi berlangsung, tetapi juga tertuju kepada segala keadaan konselor, karena konselor dipandang dan diyakini mampu sebagai orang yang mampu menyelesaikan masalahnya.

Oleh karena itu, sifat keteladanan yang dimiliki konselor perlu diekspresikan dalam kehidupan sehari-hari, baik selama proses konsultasi maupun di luar kegiatan tersebut. Minimal harus diupayakan klien/konseli dapat terkondisikan oleh sikap dan perilaku konselor, baik secara disadari atau tidak.

Situasi keteladanan itu tercipta tidak hanya terbatas pada waktu konsultasi berlangsung, tetapi di luar kegiatan itu hendaknya tetap dirasakan manfaatnya. Keteladanan dimaksud dipandang sebagai suatu hal yang sangat bermakna bagi klien/konseli terutama selama berlangsungnya proses konseling Islami. Dalam konteks pendidikan Islam memandang bahwa keteladanan dalam pendidikan adalah sarana (wasilah) yang paling aplikatif dalam upaya mencapai 
tujuan pendidikan serta menempatkan qudwah hasanah sebagai metode pencapaian tujuan. Oleh sebab itu, mu'allim (guru) haruslah mencerminkan keteladanan bagi muta'allim (peserta didik).

Dalam sejarah perjalanan misi Islam, baik pada kurun Makkah maupun pada kurun Madinah, keliatan dengan jelas bahwa keberhasilan penyiaran Islam terutama disebabkan oleh keteladanan yang dicerminkan Rasulullah dalam kehidupannya sehari-hari pada setiap aspeknya. Sangat beralasan apa yang ditegaskan Allah dalam surat al-Ahzab (33) ayat 21, bahwa Rasulullah adalah contoh teladan paling baik bagi manusia.

Sehubungan dengan konseling Islami, tidak dapat disangkal bahwa konselor dijadikan cermin oleh para klien/konselinya. Oleh sebab itu, konselor dituntut untuk dapat memantulkan cahaya keIslaman sebagi qudwah (keteladanan) dan sekaligus menjadikannya sebagai salah satu teknik penyelenggaraan konseling Islami, demi terciptanya suatu kondisi keteladanan yang mempengaruhi klien/konseli menuju arah terciptanya insan kamil.

Pelayanan Konseling Islami di madrasah merupakan usaha membantu peserta didik dalam mengembangkan kehidupan pribadi, kehidupan sosial, kegiatan belajar, serta perencanaan dan pengembangan karir. Pelayanan konseling Islami memfasilitasi pengembangan peserta didik secara individual, kelompok, atau klasikal, sesuai dengan kebutuhan, potensi, bakat, minat, perkembangan, kondisi, serta peluang-peluang yang dimiliki. Pelayanan ini juga membantu mengatasi kelemahan dan hambatan serta masalah yang dihadapi peserta didik.

Tujuan Konseling Islami yang terkait dengan aspek akademik (belajar) diantaranya adalah; a) Memiliki kesadaran tentang potensi diri dalam aspek belajar, dan memahami berbagai hambatan yang mungkin muncul dalam proses belajar yang dialaminya, b) Memiliki sikap dan kebiasaan belajar yang positif, seperti kebiasaan membaca buku, displin dalam belajar, mempunyai perhatian terhadap semua pelajaran, dan aktif mengikuti semua kegiatan belajar yang diprogramkan, c) Memiliki motif yang tinggi untuk belajar sepanjang hayat, d) Memiliki keterampilan atau teknik belajar yang efektif, seperti keterampilan membaca buku, menggunakan kamus, mencatat pelajaran, dan mempersiapkan diri menghadapi ujian, e) Memiliki 
keterampilan untuk menetapkan tujuan dan perencanaa pendidikan, seperti membuat jadwal belajar, mengerjakan tugas-tugas, memantapkan diri dalam memperdalam pelajaran tertentu, dan berusaha memperoleh informasi tentang berbagai hal dalam rangka mengembangkan wawasan yang lebih luas, f) Memiliki kesiapan mental dan kemampuan untuk menghadapi ujian.

Dalam konsep Islam, pengembangan diri merupakan sikap dan perilaku yang sangat diistimewakan. Manusia yang mampu mengoptimalkan potensi dirinya, sehingga menjadi pakar dalam disiplin ilmu pengetahuan dijadikan kedudukan yang mulia di sisi Allah swt. Hal ini diperkuat oleh Firman Allah yang terkandung dalam QS al-Mujadalah (58): 11.

Konseli sebagai individu yang sedang berada dalam proses berkembang atau menjadi (on becoming), yaitu berkembang ke arah kematangan atau kemandirian. Untuk mencapai kematangan tersebut, konseli memerlukan bimbingan karena masih kurang memiliki pemahaman atau wawasan tentang dirinya dan lingkungannya, juga pengalaman dalam menentukan arah kehidupannya. Di samping itu, terdapat suatu keniscayaan bahwa proses perkembangan konseli tidak selalu berlangsung secara mulus, atau bebas dari masalah. dengan kata lain, proses perkembangan itu tidak selalu berjalan dalam alur linier, lurus, atau searah dengan potensi, harapan, dan nilai-nilai yang dianut.

Perkembangan konseli tidak lepas dari pengaruh lingkungan, baik fisik, psikis, maupun sosial. Sifat yang melekat pada lingkungan adalah perubahan. Perubahan yang terjadi dalam lingkungan dapat memengaruhi gaya hidup (life style) warga masyarakat. Apabila perubahan yang terjadi itu sulit diprediksi, atau di luar jangkauan kemampuan, maka akan melahirkan kesenjangan perkembangan perilaku konseli, seperti terjadinya stagnasi (kemandegan) perkembangan, masalah-masalah pribadi atau penyimpangan perilaku.

Perubahan lingkungan yang diduga memengaruhi gaya hidup, dan kesenjangan perkembangan tersebut, diantaranya: perkembangan jumlah penduduk yang cepat, pertumbuhan kotakota, kesenjangan tingkat sosial ekonomi masyarakat, revolusi 


\section{Konseling Islami sebagai Intervensi bagi Remaja Berisiko di Madrasah}

teknologi informasi, pergeseran fungsi atau struktur keluarga, dan perubahan struktur masyarakat dari agraris ke industri.

Iklim lingkungan kehidupan yang kurang sehat, seperti: maraknya tanyangan pornografi di televisi, penyalahgunaan alat kontrasepsi, minuman keras, dan obat-obat terlarang/narkoba yang tak terkontrol, ketidakharmonisan dalam kehidupan keluarga, dan dekadensi moral orang dewasa yang sangat mempengaruhi pola perilaku dan gaya hidup konseli (terutama pada usia remaja) yang cenderung menyimpang dari kaidah-kaidah moral (akhlak mulia), seperti pelanggaran tata tertib sekolah/madrasah, tawuran, meminum minuman keras, menjadi pecandu narkoba atau NAPZA (narkotika, psikotropika, dan zat adaktif lainnya, seperti ganja, narkotika, ectasy, putau dan sabu-sabu), kriminalitas, dan pergaulan bebas (free sex).

Penampilan perilaku remaja seperti di atas sangat tidak diharapkan, karena tidak sesuai dengan sosok pribadi manusia Indonesia yang dicita-citakan, seperti yang tercantum dalam tujuan pendidikan nasional (UU No 20 Tahun 2003), yaitu : a)Beriman dan bertakwa kepada Allah Tuhan yang Maha Esa; b) Berakhlak mulia; c) Memiliki pengetahuan dan ketrampilan; d) Memiliki kesehatan jasmani dan rohani; e) Memiliki kepribadian yang mantap dan mandiri, serta f) Memiliki rasa tanggung jawab kemasyarakatan dan kebangsaan. Tujuan tersebut mempunyai aplikasi imperative (yang mengharuskan) bagi semua tingkat satuan pendidikan untuk senantiasa memantapkan proses pendidikannya secara bermutu ke arah pencapaian tujuan pendidikan tersebut.

\section{Simpulan}

Eksistensi remaja yang ingin mencari jadi dirinya justru menjadi berubah menjadi lupa pada jati dirinya sebagai manusia fitrah/suci, jauh dari TuhanNya yaitu Allah swt, berani melakukan kemaksiatan dan dosa, tidak taat beribadah, dan ibadahnya tidak membuat remaja bertambah iman dan mengubah perilakunya. Pemahaman kepada norma agama dan berakhlak karimah sangat kurang, lingkungan dan pola asuh yang dikembangkan di keluarga sangat mempengaruhi tatanan perilaku kepribadian remaja itu sendiri, remaja yang resilien dan berprestasi juga ditentukan oleh 
peran serta lingkungan dan pendidikan akhlak dari orang tua, penanaman keimanan dan melaksanakan ajaran-ajaran keislaman yang baik. Dan perilaku remaja akan menjadi berbahaya dan penuh resiko juga dipengaruhi pula oleh situasi lingkungan pergaulan remaja yang tidak sehat, motif berprestasi yang sangat rendah, pola asuh dan budaya dalam keluarga yang permisif yang cenderung tanpa kontrol, penguatan agama dan akidah yang rendah serta minimnya teladan atau model dari orang tua. Oleh karena itu Konseling Islami di madrasah akan sangat berperan pada posisi sentral sebagai penguat dalam mengembangkan potensi remaja, membina, mencegah, mengarahkan dan bahkan mengentaskan remaja dari perilaku-perilaku yang berisiko.

Asas Pelayanan Konseling Islami di madrasah tentunya mengakar pada al-Quran dan al Hadist yang menjadi pegangan pokok kehidupan manusia. Sebagai konselor di madrasah tentunya pemberian konseling harus berbasis nilai-nilai Islami yang merupakan rujukan untuk mengelola perilaku remaja dalam menuai kebahagiaan dunia maupun akherat. 
Konseling Islami sebagai Intervensi bagi Remaja Berisiko di Madrasah

\section{Daftar Pustaka}

Az-zahrani, Musfir bin Said, 2005, Konseling Terapi. Jakarta: Gema Insani.

Geldad, Kathryn (ed), 2012, Konseling Remaja Intervensi Praktis Bagi Remaja Berisiko, Yogyakarta: Pustaka Pelajar.

Hurlock, Elisabeth, 1980, Psikologi Perkembangan. Jakarta: Erlangga.

Nurihsan, Achmad Juntika, 2006, Akhlak Mulia dalam Perspektif Bimbingan dan Konseling Islami. Bandung: Rizki Press.

Saptadi Ismanto, Heri, 2016, Konseling Teman Sebaya untuk Mencegah Perilaku Berisiko pada Remaja, Semarang: Seminar Nasional BK FIP UPGRIS.

Sudarsono, R, 1995, Kenakalan Remaja, Jakarta: Rineka Cipta.

Sutoyo, Anwar, 2013, Bimbingan dan Konseling Islami. Yogyakarta: Pustaka Pelajar. 